\title{
Usage of Islamic Alms’s Online Portal: Case Study on Pusat Pungutan Zakat (PPZ), Federal Territories of Malaysia
}

\section{Muhsin Nor Paizin*}

Senior Research Executive, Research and Corporate Development Unit, Pusat Pungutan Zakat (PPZ), 68-1-6, Dataran Shamelin, Jalan 4/91, Taman Shamelin Perkasa, 56100 Kuala Lumpur, Malaysia

\begin{abstract}
Positive achievement of zakat institutions in carrying out their duties as an organization is heavily influenced by the strategy of usage in latest technology. This statement is supported when we saw the dissemination of information, with variety of means of payment that may changes the traditional sytem to online and electronic system. Hence, this paper will highlights some background of development of zakat institutions especially PPZ, which preceded by an explanation of the duties and responsibilities of zakat institutions in Federal Territories of Malaysia. Then, this paper will describe status of current performance of PPZ websites then indentify some factors contributing improvement through analysis of the survey results. Some suggestions also will be featured. As we know, the process of websites development often face many difficulties that need to be addressed. Various important element should be discussed as to serve a useful input to webmaster also the institution itself so it will make the websites be more effective as per what religion of Islam hope.
\end{abstract}

Keywords: Technological development; Websites; Zakat; Improvemnet; Federal Territories of Malaysia

\section{Introduction}

Zakat from Arabic term is clean, pure, grow and develop while can also be interpreted as an act of mercy, kindness, purification and improvement. Zakat in a term point of view is act of outgo of particular part from the property, given to specific recipients who are entitled to certain conditions. As one of the five pillars of Islam, zakat has a strong background in the construction of Islam as a whole. From this intorduction, zakat can be easily deemed as financial and social catalyst in Islam.

Zakat in Islam is a religious obligation to Muslims which have a significant influence on the Islamic country's administrative system. Zakat is a financial management tool that aims to overcome poverty and hardship by placing the responsibility on those who are rich against the recipients (asnaf) which was clearly stated in the Quran. The importance of zakat in a country's implementation is to ensure justice and social stability as well as bridging the gap between societies and avoid the occurrence of hostility and hatred among people. Although the duty of zakat is placed on individuals, yet the impact it's not only to the zakat recipients target group but also to the zakat institutions itself.

Federal Territories of Malaysia comprising of Kuala Lumpur, Putrajaya dan Labuan. The body who responsible for collecting and distributing zakat in Federal Territories of Malaysia is the Federal Territories of Islamic Religious Council (MAIWP) [1] established by section 4 (1) of the Administration of Islamic Law (Federal Territories) 1993 - Act 505 of Malaysia which states that: "There shall be a body known as the Federal Territories of Islamic Religious Council to advise the King on matters relating to the religion of Islam"

However since 1991, all operation regarding of zakat collection was conducted by a company established by the council which was named HartaSuci Private Limited which used brand name as Zakat Collection Centre (Pusat Pungutan Zakat, PPZ). The establishment is in accordance with section 8A (1) states that: "The Council may, with the approval of the King, set up a company under the Companies Act 1965 [Act 125] to carry out any activities planned or undertaken by the Council in the performance of duties or powers under section 7”. PPZ is a wholly owned subsidiary of the Federal Territory Islamic Religious Council which is responsible for carrying out the work of collection of zakat and charity efforts and deliver message of zakat to the Muslim community in the Federal Territories of Malaysia. The distributions of zakat fund were fully managed by the treasury department (Baitulmal) of MAIWP [1-4]

\section{Services in Zakat Instutions}

Since its first year establishment, PPZ has introduced various range of services with the aim of encouraging Muslims to settle their obligations of zakat. Year-by-year, PPZ has carry out development by introducing several types of zakat can be collected (al-mustaghallat) such as; Zakat on income, business, shares, gold, silver and some other kind of collection of obligatory to the Muslims, especially in Malaysia [2].

Innovative approach and continuous improvements are expected to produce a variety of ways which can facilitate zakat payers. From time to time, new type of payment channel was created such as payroll deductions, bank counter, post office counter, agents appointed, internet portals and so on. Payment growth from the most of the channels available are clearly illustrates the need for those channels [3]. The introduction of internet portal as a new zakat payment channel was started since August 2011. This kind of payment channel is expected will contibute to increment in the amount of zakat collection which can be prove by data showing below (Table 1):

Table 1 shows trend of increasing in number of collection year

*Corresponding author: Muhsin Nor Paizin, Research and Corporate Development Unit, Pusat Pungutan Zakat (PPZ), 68-1-6, Dataran Shamelin, Jalan 4/91, Taman Shamelin Perkasa, 56100 Kuala Lumpur, Malaysia, Tel: +60129108144; E-mail: muhsin.paizin@gmail.com

Received November 03, 2016; Accepted February 10, 2017; Published February 18, 2017

Citation: Paizin MN (2017) Usage of Islamic Alms's Online Portal: Case Study on Pusat Pungutan Zakat (PPZ), Federal Territories of Malaysia. Intel Prop Rights. 5: 175. doi: 10.4172/2375-4516.1000175

Copyright: (c) 2017 Paizin MN. This is an open-access article distributed under the terms of the Creative Commons Attribution License, which permits unrestricted use, distribution, and reproduction in any medium, provided the original author and source are credited. 


\begin{tabular}{|l|l|c|c|c|}
\hline No & $\begin{array}{l}\text { Internet Portal } \\
\text { Payment Channel }\end{array}$ & $\mathbf{2 0 1 3}$ & $\mathbf{2 0 1 2}$ & $\mathbf{2 0 1 1}$ \\
\hline $\mathbf{1}$ & $\begin{array}{l}\text { FPX (Financial } \\
\text { Crocess } \\
\text { Exchange) }\end{array}$ & $45,57,479.85$ & Collection (RM) & Collection (RM) \\
\hline $\mathbf{2}$ & $\begin{array}{l}\text { MIGS (Credit card } \\
\text { Internet Gateway } \\
\text { Service) }\end{array}$ & $13,16,065.82$ & $9,31,857.49$ & $8,59,205.55$ \\
\hline $\mathbf{3}$ & $\begin{array}{l}\text { Online Payroll } \\
\text { Deduction }\end{array}$ & $1,30,878.23$ & $85,917.92$ & $8,8417.51$ \\
\hline & $\begin{array}{l}\text { Jumlah } \\
\text { Keseluruhan }\end{array}$ & $\mathbf{5 8 , 7 3 , 5 4 5 . 6 7}$ & $\mathbf{4 0 , 5 5 , 3 8 2 . 2 0}$ & $\mathbf{1 1 , 4 4 , 5 2 3 . 0 6}$ \\
\hline
\end{tabular}

Source: PPZ.

Table 1: PPZ's Collection of Zakat By Online Payment Channel.

by year, thus we can say that potentially increase in number of zakat collection in the coming years, thus capable of being one of the main peyment channel zakat in PPZ. Compatible with the development of the world's view of technology and the Internet as the new main medium.

Hence, there is a need to find factors that can contribute to the use of the online channel for Portal PPZ towards improving the collection of zakat in the Federal Territories of Malaysia. The aim of this study was to review the current scenario of internet use by the public in matters relating to zakat. It is hoped that the findings can be used as input to the executor for action to improve existing services to make them more efficient and frequentedly used.

\section{Research Methodology}

Information are gathered from the primary data. Data involving 117 respondents from zakat payers who have pay zakat through the PPZ online payment channel. Period of time to receive feedback was in 2014. While the secondary data are based on information from PPZ Annual Report.

\section{Literature Review}

Development and improvement for better and easy payment process bring up the needs to introduce system which can be done using online. One of that is online payment channel. As stated from Adnan Mohammad (2008), the development of e-payments will help to improve the efficiency of the financial system by reducing cost of transactions, enhancing liquidity, and facilitating better allocation of financial resources that can bring significant benefits to all parties in the financial sector.

On the other hand, implement online services also helps to reduce operational cost such as marketing and wage cost. The payment landscape is complex and changing rapidly. Channel volumes are shifting. Technology turnover is hastening. Laws and regulations are adding complexity to the payments process. Overall economic pressures are squeezing budgets and increasing risk [5].

However, others kind of mean also been innovated as to provide the best services to customers. The most important fronts of technological innovation in the relationships with the final consumer are checkout technologies, electronic and mobile payment systems, distance selling (mainly on-line sales), and Self-Service Technologies (SSTs), such as vending machines and multimedia kiosk [6].

Online technological innovations impact the operational design of a channel system by increasing the degree to which the tasks and resources of members need to be integrated. In particular, the proper utilization of software requires the integration of channel operations in terms of greater formalization, standardization, and centralization [7].

\section{Research Findings and Discussion}

Through a survey conducted, the study found that a variety of factors that should be emphasized in the process of development and improvement of a website zakat. Each element outlined should be considered important in order to meet the needs of the community, especially those who are familiar with the latest technology (Table 2).

Table 2 shows the methods that contribute to the increase in visitors to the Portal PPZ. Preceded by the search engine system (search engine), followed by printed media such as advertisements, posters and printed materials and so on. Thus, the executor should prioritize the search engine and advertising system as a means of promoting the portal in order to reach more internet surfers. The paper believes this finding is also compatible with any website other states zakat (Table 3).

Table 3 shows the computer device (desktop and laptop) are still the main tool in the process of surfing the internet. Each website built should be commensurate with what will seen in the computer display. However, the use of other devices such as smartphones and tablets are expected to be increased from time to time on the changing trends and the latest technological developments. These factors should be considered essential for the PPZ, and it has been realized with the construction of zakat apps that can be downloaded by users of smartphones [8] (Table 4).

Table 4 reflect the popular internet browser, which is among the newest in the market for internet browser application that is preceded by the Google Chrome browser. However, there are still some who use the old browser such as Internet Explorer (IE). Hence, the zakat website shall conform to the display used by most internet users, so as to attract more visitors and enable them to engage in zakat. Among the reasons for having emphasized the type of browser is because it affects the existing security system and the speed of downloading time of the page [9].

Among the respondents, research has obtained some information from their views on why zakat payers choose PPZ online payment

\begin{tabular}{|l|c|c|}
\hline & Percentage & Total \\
\hline Search Engine (Google / Yahoo / etc) & $82.80 \%$ & 96 \\
\hline Printed media & $31.90 \%$ & 37 \\
\hline Other websites & $9.50 \%$ & 11 \\
\hline Acquaintance & $5.20 \%$ & 6 \\
\hline Not sure & $0.90 \%$ & 1 \\
\hline
\end{tabular}

Table 2: Method to Discovered PPZ's Portal.

\begin{tabular}{|l|c|c|}
\hline & Percentage & Total \\
\hline Dekstop / Laptop & $63.50 \%$ & 73 \\
\hline Smartphone & $29.60 \%$ & 34 \\
\hline Tablet (Apple iPad / Samsung Tab / etc) & $6.10 \%$ & 7 \\
\hline Others & $0.90 \%$ & 1 \\
\hline
\end{tabular}

Table 3: Internet Surfing Devices.

\begin{tabular}{|l|c|c|}
\hline & Percentage & Total \\
\hline Goggle Chrome & $55.70 \%$ & 64 \\
\hline Internet Explorer & $21.70 \%$ & 25 \\
\hline Mozilla Firefox & $20.00 \%$ & 23 \\
\hline Opera & $0.90 \%$ & 1 \\
\hline Others & $1.70 \%$ & 2 \\
\hline
\end{tabular}

Table 4: Popularity of Surfing Internet Application. 


\begin{tabular}{|c|c|c|c|c|c|c|}
\hline Factors & 1 & 2 & 3 & 4 & 5 & Average Score \\
\hline Simplify the payment process & 8 & 8 & 14 & 37 & 45 & 3.92 \\
\hline Time saving & 10 & 12 & 12 & 38 & 40 & 3.77 \\
\hline Information provided & 7 & 52 & 29 & 9 & 15 & 3 \\
\hline Assured securities & 12 & 25 & 44 & 21 & 10 & 2.93 \\
\hline Interesting web design & 74 & 15 & 13 & 7 & 2 & 1.63 \\
\hline
\end{tabular}

Table 5: General Facts for Reason to Pay Zakat Using PPZ's Online Payment Channel.

channels as a mechanism. Scale of 1 indicates the least important factor, while the scale 5 indicating the most important factor (Table 5), [10].

Table 5 shows from the view of respondents, the main factors payers pay zakat through the website is 1) to simplify and facilitate the payment process and followed by a factor of 2) time saving. Two factors greatly meet the main goal of the online portal channel which was created to facilitate the community's difficulties to do the payments through other channels, as well as helping them to save time. Other factors that are no less important in contributing is a factor of 3) availability of information, which has a lot of explanation and answer of the problems and methods of calculating zakat (calculator) provided; and also a factor of 4) cyber security which is very important and should be assured all the time. While a factor of 5) design of the website was not much contribute to the acceptance of the payment channel, but it should not be totally ignored because to some extent shows the level of professionalism of zakat institutions in managing their websites [11-13].

\section{Suggestion}

Based on the results and discussion, the paper saw some elements that could be incorporated into the operational management of zakat institution's website. In creating an effective web site, the developement process should be able to suit the current scenario and internet use by the public. Some proposals outlined, namely:

\section{Accessible}

The website should be easily accessible and can easily be found primarily through search engine system. This is because, it opens up more opportunities for internet surfers to find sites that are required, thus potentially become customers. Among other things also help in the process of propagation and dissemination of information to the public along with the obligatory zakat institution itself which has the task to explain the importance and ways to perform zakat.

\section{Suitable with main and popular devices}

Each website should be developed in accordance with the gaze of the most popular device which is the computer. But not necessarily waive the future of high potential device such as smartphone and tablet. This is due to the increased use of these devices should be considered important. Thus, the task of building applications (apps) that effective and appropriate should be carried out immediately in order for Muslims community to learn about zakat.

\section{Various intermediate language}

The intermediate language which contained in a website should be diversified and not limited to the Malay and English language only. With the diversity of languages used, more visitors can obtain information regarding zakat in particular attracting visitors from abroad.

\section{Constantly updated information}

Diversify and regularly update information. This is one important factor that would distinguish a visitor into a paying zakat or just purely internet surfer. Availability information which is continuously updated are to show that a website is effective, efficient and more user-friendly.

\section{Simple but attractive design}

Website design should be attractive but simple because it will help shorten the download time. Such facts is to attract people to browse and approaching these sites. Web page management especially in term of its size should be small so that it will efficiently prevent users dealing with difficulties, especially those have slow internet bandwith connection.

\section{Meets the objectives of the establishment}

The most important factor is that each web page development and improvement of zakat must be anchored to facilitate the payment of zakat from customers. This is because online channels should be established to facilitate the community's difficult to perform zakat through other channels. In fact not only facilitate individual and society, as well as to companies, banks and entrepreneurs. All payment transactions, registration, questions, and all other related matters should and can be done quickly and easily.

\section{Conclusion}

Website development system PPZ are recognized to attracted muslims community to perform zakat which can be seen from achievement of the total collections. IT systems have been seen as a medium of communication and information play an important role in disseminating information and promoting zakat. Last but not least it is an important medium in the process of collecting zakat. The website for example, will gradually become the prime mover in the process of dissemination of information and means of payment, by the institution of zakat should not assume this technology simply as a sideline activity only. It is time for any zakat institutions to improve the use of technology and internet in all affairs that all Muslims are able to fulfill their duties.

\section{References}

1. Pusat Pungutan Zakat Majlis Agama Islam Wilayah Persekutuan (PPZ-MAIWP) Annual Report 2013: PPZ-MAIWP.

2. Pusat Pungutan Zakat Majlis Agama Islam Wilayah Persekutuan (PPZ-MAIWP) Annual Report 2012: PPZ-MAIWP.

3. Pusat Pungutan Zakat Majlis Agama Islam Wilayah Persekutuan (PPZ-MAIWP) Annual Report 2011: PPZ-MAIWP.

4. Muhammad YI (2007) Pelaksanaan Agihan Zakat Majlis Agama Islam Persekutuan (MAIWP) JAWHAR Management Journal 1: 45 - 52.

5. Plymouth K, Martin J (2009) Bill Payment Trends: Major Shifts in Consumer Behavior Require Comprehensive Planning.: First Data Corporation.

6. Musso F, Consoli D (2010) Technology In marketing Channels: Present And Future Drivers Of Innovation. Paper from The International Conference on Economics and Administration, Faculty of Business and Administration, University of Bucharest, Romania, ICEA-FAA Bucharest, 4-5th June 2010.

7. Daniel CB, Osmonbekov T, Tian XF, Gilliland D (2002) E-Business Technological Innovations. Journal of Marketing Channels 9: 3-25. 
Citation: Paizin MN (2017) Usage of Islamic Alms's Online Portal: Case Study on Pusat Pungutan Zakat (PPZ), Federal Territories of Malaysia. Intel Prop Rights. 5: 175. doi: 10.4172/2375-4516.1000175

Page 4 of 4

8. http://www.kosmo.com.my

9. Muhammad A (2008) The Development Of E-Payment And Challenges In Malaysia. The Development of E-Payments and Challenges for Central Banks in the SEACEN Countries 5: 123-157.

10. Noordin FM (2009) ICT and Islam: IIUM Press, IIUM.

11. Muhsin NP (2013) Aplikasi Laman Web Dalam Institusi Zakat Di Malaysia
Ke Arah Penambahbaikan Keberkesanannya: Islamic Perspective On Management: Contemporary Issues. Universiti Malaya Press 375-388.

12. Muhsin NP (2014) Practice of Da'wah in Zakat (Islamic Alms) in Federa Territory, Malaysia: An Observation. International Proceedings of Economics Development and Research: IACSIT Press.

13. Sukor N (2007) Pembangunan Laman Web: Keberkesanannya Dan FaktorFaktor Kritikal Supaya Penggunaannya Lebih Efektif: JAWHAR Management Journal 1: 165-176. 